\title{
ЧЕЛОВЕК УДИВИТЕЛЬНОЙ ДУШИ (памяти Б.С. КРЫЛОВА)
}

В.И. Фадеев

Аннотация. Статья посвящена профессору Борису Сергеевичу Крылову, его жизненному и научному пути. В ней освещаются основные вехи его долгой и яркой жизни ученого, педагога, гражданина, патриота, участника Великой Отечественной войны. Показан вклад Б.С. Крылова в разработку многих проблем конституционного права: парламентаризма, федерализма, суверенитета, конституционализма, прав человека и др. В статье отмечается, что Б.С. Крылов был не только глубоким и самобытным ученым, но и прекрасным педагогом, отдающим много сил повышению уровня гуманитарного развития студентов, их патриотическому воспитанию. Он располагал к себе своей интеллигентностью, своими глубокими научными и жизненными по-знаниями. Его любили студенты, к нему внимательно прислушивались аспиранты, его ценили и уважали коллеги-преподаватели, отдавая должное его знаниям, эрудиции, замечательным качествам его души и характера. Особо значим вклад Б.С. Крылова в развитие науки конституционного права зарубежных стран. Ко многим его работам применимо слово «впервые». Его докторская диссертация - это, по сути, первая в советской литературе фундаментальная работа, посвященная парламенту и парламентаризму зарубежных стран, написанная на основе многочисленных зарубежных источников, многие из которых ученый впервые ввел в научный оборот. $\mathrm{OH} \mathrm{часто} \mathrm{публиковал} \mathrm{в} \mathrm{советский} \mathrm{период} \mathrm{статьи,} \mathrm{в} \mathrm{которых} \mathrm{дана} \mathrm{характеристика}$ состояния науки конституционного права зарубежных стран, проанализированы новейшие научные труды зарубежных авторов. По мнению Бориса Сергеевича, будущее страны требует усиления центральной власти и одновременно расиирения демократических начал в организации всех ее звеньев. Именно это сочетание, считал он, способно обеспечить дальнейшее расширение прав и свобод человека и гражданина. $B$ своих работах ученый призывает законодателя учитывать, что российский фредерализм нельзя считать последовательным, что он вырос из унитарного государства, каким фактически был Советский Союз. Б.С. Крылов отмечал, что в каждой федерации полномочия центра и мест устанавливаются с учетом исторических традиций и местных условий, политического развития населения. По его мнению, важно, чтобы федеративные отношения не подвергались постоянным изменениям и основывались на стабильных конституционных нормах и принципах. Обращаясь к проблеме равноправия и равенства в конституционном праве, отмечал, что эта проблема имеет особое значение в условиях федеративного государства. Он исходил из того, что все субъекты входят в состав Российской Федерации на равных основаниях. Неравноправие субъектов, а значит и их органов, по его мнению, означало бы, что находящиеся на территории различных субъектов РФ граждане также неравноправны.

Ключевые слова: юриспруденция, Б.С. Крылов, конституционное право, парламентаризм, федерализм, суверенитет, Военно-юридическая академия, Университет имени О.Е.Кутафина, конституционализм, Конституция РФ.

DOI: 10.7256/1729-5920.2014.1.10364

(C) Фадеев Владимир Иванович

* Доктор юридических наук, профессор, заведующий кафедрой конституционного и муниципального права Московского государственного юридического университета имени О.Е. Кутафина (МГЮА)

[vifadeev@mail.ru]

123995, Москва, ул. Садовая-Кудринская, д. 9. 
Ю ридическая наука понесла тяжелую утрату. На 91-м году жизни 25 ноября 2013 г. скончался Борис Сергеевич Крылов - ветеран Великой Отечественной войны, доктор юридических наук, профессор кафедры конституционного и муниципального права Московского государственного юридического университета имени О.Е.Кутафина (МГЮА), заслуженный деятель науки РФ.

Борис Сергеевич был уникальной личностью: человеком удивительной души, культуры, обаяния, интеллигентности, ума. Он был необычайно добрым, великодушным, внимательным ко всем, с кем ему приходилось общаться. Но вместе с тем в вопросах, которые он считал принципиальными, был тверд, последовательно и убедительно отстаивал свою позицию, свой взгляд на ту или иную проблему. Умел сказать - «нет», хотя от него в той или иной ситуации ждали иного ответа.

Б.С. Крылов прожил долгую и яркую жизнь. В нем удивительным образом сочетались лучшие черты дореволюционной и советской интеллигенции.

Жизнь государства и общества основывается не только на нормах конституции и законов, но и на глубоких традициях, которые выступают как духовные скрепы в жизни каждого народа. Их носителями являются люди, которые своими поступками и делами, работой и творчеством поддерживают и развивают эти великие традиции своего народа, выступая связующей нитью поколений. Таким человеком являлся Б.С. Крылов. Он был патриотом своей Родины. Ее судьбы волновали его как гражданина, как ученого. В своих работах он привлекал внимание к острым проблемам развития России как правового демократического федеративного государства, предлагал пути их решения.

Б.С. Крылов - человек, который вслед за поэтом военных лет М. Кульчицким мог бы сказать:

«Не до ордена.

Была бы Родина

с ежедневными Бородино».

Если попробовать найти краткое и емкое определение дела всей его жизни, то можно сказать - это служение. Служение своей стране, своему народу, служение науке. И началось это служение для студента исторического факультета Ленинградского университета Бориса Крылова 22 июня 1941 г., когда добровольцем ушел на фронт защищать свой город, свою страну, свой народ.

Война перевернула жизнь многих миллионов людей. Изменила она и жизнь Бориса
Сергеевича. Он не стал историком, а, окончив Военно-юридическую академию, стал юристом. Возможно не только война, не только служба в аппарате военного трибунала повлияли на его выбор жизненного пути. Сказались и традиции, которые были в его семье. Военным был его дед по отцовской линии, который вышел в отставку в чине генерала; юристом был его отец - выпускник юридического факультета Санкт-Петербургского университета, который ушел добровольцем в Первую мировую войну, закончив ее после тяжелого ранения в чине штабс-капитана. Юридическое образование имела мама Бориса Сергеевича, которая была медсестрой в Первую мировую войну и успела до революции получить юридическое образование. Дед по материнской линии был в свое время мировым судьей.

Истоки каждого человека - его мировоззрение, его духовный и нравственный облик берут начало, закладываются прежде всего и главным образом в семье. Поэтому о родителях Бориса Сергеевича надо рассказать чуть подробнее.

Отец Бориса Сергеевича - Сергей Борисович Крылов - выдающийся советский юрист-международник, доктор юридических наук, профессор государственного и международного права, заслуженный деятель науки РСФСР. Был членом делегации СССР и принимал активное участие в выработке Устава ООН. Вместе с другими членами советской делегации подписал Устав ООН, участвовал в Вашингтонской сессии Комитета юристов (1945 г.) и первой сессии Генеральной Ассамблеи ООН. В 1946 г. избран членом Международного суда $\mathrm{OOH}$.

Мама Бориса Сергеевича - Ева Николаевна Окунева - родом из старинного города Устюжна Вологодской области (где в 1923 г. родился и Борис Сергеевич), училась на Бесстужевских курсах, получила юридическое образование, хотя в те времена для женщин это было непросто.

Будучи на фронте, Борис Сергеевич в день своего рождения - 11 января 1942 г. получил письмо от своей мамы, которое он бережно хранил всю свою жизнь. Это письмо стало для него талисманом, его опорой в военной жизни.

Б.С. Крылов Военно-юридическую академию (ВЮА) окончил в 1947 г., а в 1951 г. в этой же Академии защитил кандидатскую диссертацию. Его научным руководителем был Всеволод Николаевич Дурденевский - один из признанных корифеев науки международного и конституционного права зарубежных стран, 
получивший юридическое образование еще до революции.

Надо отметить, что в ВЮА работали, учились, защищали кандидатские и докторские диссертации в разные годы выдающиеся советские ученые: М.С. Строгович, С.Н. Братусь, В.М. Чхиквадзе, В.Д. Меньшагин, П.Н. Галанза, А.Е. Лунев, Б.П. Кравцов, В.Н. Кудрявцев, М.И. Козырь, Н.Я. Куприц, Е.А. Скрипилев, С.С. Студеникин, Р.С. Белкин, Н.А. Стручков, Б.В. Щетинин и др. Это была школа подготовки высококлассных юристов для работы в органах юстиции Вооруженных Сил СССР.

После защиты кандидатской диссертации в 1951-1956 гг. Б.С. Крылов преподавал в родной Академии. В 1956 г. Военно-юридическая академия была расформирована, и Борис Сергеевич перешел на работу в Институт международных отношений, а затем - Институт государства и права АН СССР, где в 1963 г. защитил докторскую диссертацию.

Борис Сергеевич работал в разных вузах, в разных научно-исследовательских учреждениях. При этом, как и его отец, он совмещал активную научную и преподавательскую деятельность с работой в различных комиссиях, экспертных советах при органах государственной власти. Борис Сергеевич участвовал в работе над многими законопроектами. Его глубокие знания парламентской деятельности были востребованы при подготовке проектов документов, связанных с формированием палат федерального парламента, при совершенствовании его регламентной практики ${ }^{1}$. Много времени Б.С. Крылов отдавал развитию международных контактов с иностранными коллегами, участвуя в конференциях, круглых столах и т.п. Он принимал активное участие в работе Союза советских обществ дружбы и культурной связи с зарубежными странами (ССОД), выезжал за границу в целях развития и укрепления дружбы и культурного сотрудничества народов нашей страны с народами других государств. В 90-е гг. прошлого века он, как бы продолжая работу своего отца в ООН, согласно распоряжению Президента РФ от 1 апреля 1996 г. возглавлял делегацию Российской Федерации в Комиссии ООН по правам человека.

Сорера научных интересов Б.С. Крылова весьма широка: парламентаризм, фредерализм, суверенитет, правовые проблемы национальных отношений, вопросы государ-

Крылов Б.С. Парламент буржуазного государства. Политическая сущность и формы парламента и парламентаризма на современном этапе. М., 1963. ственной идеологии, международного права и др. Он автор более 140 публикаций, среди которых: Государственный строй Великобритании (М., 1957); Парламент буржуазного государства. Политическая сущность и формы парламента и парламентаризма на современном этапе (М., 1963); США: фредерализм, штаты и местное управление (М., 1968); Полиция США. Основные черты организации и деятельности (М., 1972) и др. Он является соавтором ряда монографий, а также учебников по государственному (конституционному) праву, учебных пособий по спецкурсам, автором многочисленных научных статей.

В 2013 г. - к своему 90-летию - Борис Сергеевич издал монографию «Проблемы влияния идеологии на общество и государство».

Его вклад в развитие науки конституционного права зарубежных стран особо значим. Ко многим его работам применимо слово «впервые». Его докторская диссертация - это, по сути, первая в советской литературе фундаментальная работа, посвященная парламенту и парламентаризму зарубежных стран, написанная на основе многочисленных зарубежных источников, многие из которых Борис Сергеевич впервые ввел в научный оборот. Борис Сергеевич часто публикует в советский период статьи, в которых дается характеристика состояния науки конституционного права зарубежных стран, анализируются новейшие научные труды зарубежных авторов ${ }^{2}$.

Работая в Высшей школе МВД СССР с 1969 г. и будучи начальником кафредры государственно-правовых дисциплин в период с 1971 по 1983 гг., публикует ряд работ, в которых впервые в советской литературе так основательно анализируются вопросы организации гражданской службы, полиции и др. Особенностью этих работ являлось то, что, помимо критики зарубежного опыта, автор обращал внимание на то, что могло быть использовано и при организации государственной службы, милиции в наших условиях ${ }^{3}$.

Особый период его жизни - работа в Институте законодательства и сравнительного правоведения при Правительстве РФ (с 1983 по 2002 гг.). Именно в это время, возглавляя

Например: Крылов Б.С. Критика современных буржуазных теорий парламентаризма // Советское государство и право. 1962. № 1. С. 111-115; Его же. Английская политологическая литература: проблемы Британского государства и демократии // Советское государство и право. 1983. № 5. С. 146-150.

Например: Крылов Б.С. Полиция США. Основные черты организации и деятельности: учебное пособие. M., 1972. 
отдел правовых проблем федеративных и национальных отношений ${ }^{4}$, публикуя многочисленные работы, Борис Сергеевич проявляет себя как ведущий специалист в этой области ${ }^{5}$. Ему помогает в этом блестящее знание теории федерализма, зарубежного опыта развития федеративных государств ${ }^{6}$.

Еще в 1959 г. он публикует работу, посвященную анализу тенденций развития федерации в зарубежных странах, в 1968 г. издает фундаментальную работу «США: фредерализм, штаты и местное управление». Это было первое в советской литературе исследование, посвященное системному анализу данных вопросов.

В период перестройки, когда происходят существенные изменения в федеративном устройстве нашего государства, Б.С. Крылов активно участвовал во всевозможных дискуссия ${ }^{7}$, обсуждениях, разрабатывал проекты документов по проблемам развития фредеративных отношений. Возглавляемый им отдел Института законодательства и сравнительного правоведения работал над проектом Союзного договора, впоследствии - Федеративного договора 1992 г. 8

В 1990 г. в соавторстве с докторами наук Надеждой Александровной Михалевой и Игорем Николаевичем Кузнецовым Борис Сергеевич публикует Концепцию союзного договора, в которой предлагались пути решения вопроса о сохранении обновленного Союза $\mathrm{CCP}^{9}$.

Крылов Б.С. Отдел правовых проблем федеративных и национальных отношений // Институту законодательства и сравнительного правоведения 75 лет. М., 2000. C. 33-37.

Крылов Б.С. Разграничение предметов ведения и полномочий в Российской Федерации: поиск оптимальных путей // Журнал российского права. 1997. № 1. C. $78-85$.

Например: Крылов Б.С. О различных тенденциях развития федерации в зарубежных государствах // Coветское государство и право. 1959. № 9. С. 62-71; Его же. Федерализм и его будущее // Ежегодник российского права. 1999. М., 2000. С. 78-85.

Крылов Б.С. Модели федерализма и федерации. Строительство общеевропейского дома. Федерация в свете права народов на самоопределение // Международная конференция «Право и европейское сотрудничество»: сборник тезисов выступлений. Лондон, 1991. C. $7-8$.

Ильинский И., Крылов Б., Михалева Н. Федеративный договор и правовая система Российской Федерации // Конституционный вестник. М., 1992. № 14 C. 20-31.

Крылов Б.С., Кузнецов И.Н., Михалева Н.А. Концепция союзного договора // Советское государство и право. 1990. № 10. С. 3-13.
В 90-е гг. прошлого века отдел Института законодательства и сравнительного правоведения, который возглавлял Б.С. Крылов, разрабатывает концепцию развития законодательства в сфрере фредеративных, региональных и национальных отношений. Основные положения Концепции были сформулированы и обоснованы Б.С. Крыловом в статье, опубликованной в сборнике Института «Концепции развития российского законодательства» ${ }^{10}$.

Борис Сергеевич был убежденным сторонником развития России как федеративного государства ${ }^{11}$. По его мнению, закрепление федеративного устройства России в Конституции 1993 г. было неизбежным в силу двух обстоятельств. Во-первых, отказ от федеративной формы мог быть расценен определенной частью населяющих страну народов как игнорирование их национальных интересов; во-вторых, в такой огромной стране, как Россия, было бы неразумно решать все проблемы в центре ${ }^{12}$.

При этом Б.С. Крылов в своих работах призывает законодателя учитывать, что российский федерализм нельзя считать последовательным, что он вырос из унитарного государства, каким фрактически был Советский Союз. Ученый отмечал, что в каждой федерации полномочия центра и мест устанавливаются с учетом исторических традиций и местных условий, политического развития населения. По его мнению, важно, чтобы федеративные отношения не подвергались постоянным изменениям и основывались на стабильных конституционных нормах и принципах.

Борис Сергеевич, обращаясь в одной из своих работ к проблеме равноправия и равенства в конституционном праве, отмечает, что эта проблема имеет особое значение в условиях федеративного государства. Он исходил из того, что все субъекты входят в состав Российской Федерации на равных основаниях. Неравноправие субъектов, а значит и их органов, по его мнению, означало бы, что находящиеся на территории различных субъектов РФ граждане также неравноправны. Исторический опыт многих федеративных

10 Крылов Б.С. Концепция развития законодательства в сфере федеративных, региональных и национальных отношений// Концепции развития российского законодательства. М., 1998.

11 Крылов Б.С. Российский федерализм - гарантия демократии и прав человека // Журнал российского права. 2000. № 1. С. 7-16.

12 Крылов Б.С., Невинский В.В. Российский федерализм на перекрестке мнений // Российский юридический журнал. Екатеринбург, 2007. № 5. С. 57-63. 
государств, указывал Б.С. Крылов, свидетельствует, что неравноправие их субъектов обычно приводит к искажению самой сущности федерации ${ }^{13}$.

По мнению Б.С. Крылова, будущее страны требует усиления центральной власти и, одновременно, расширения демократических начал в организации всех звеньев власти. Именно это сочетание способно обеспечить дальнейшее расширение прав и свобод человека и гражданина.

В нашем многонациональном государстве, подчеркивал Б.С. Крылов, особенно значимо право человека на поддержание национальных традиций и традиционного образа жизни ${ }^{14}$. Поэтому Борис Сергеевич обосновывал необходимость принятия федерального закона о гарантиях прав национальных меньшинств и лиц, к ним относящихся, считая, что уже имеющееся законодательство о коренных малочисленных народах создало предпосылки для решения проблем национальных меньшинств в целом, но не решило их ${ }^{15}$.

В своих работах Б.С. Крылов неоднократно обращается к проблемам суверенитета государства ${ }^{16}$. Он не мог согласиться с мнением тех ученых и политиков, которые утверждают, что понятие суверенитета сегодня уже не имеет правового значения, что суверенитет может быть ограничен и что пределы суверенных прав государства должны определяться не самим государством, а какими-то наднациональными силами. Эти взгляды, считал Борис Сергеевич, несут угрозу самому существованию независимых государств, праву народа самостоятельно определять пути своего развития ${ }^{17}$.

Борис Сергеевич был не только глубоким и самобытным ученым, но и прекрасным педагогом. Несомненный интерес представляет его работа, посвященная проблемам юридического образования в современной России.

\footnotetext{
13 Крылов Б.С. Проблемы равноправия и равенства в российском конституционном праве // Журнал российского права. М., 2002. № 11. С. 13-24.

14 Крылов Б.С., Невинский В.В. Указ. соч. С. 58, 60.

15 Крылов Б.С. Проблемы защиты прав национальных меньшинств в Российской Федерации // Россия и Совет Европы: перспективы взаимодействия : сборник докладов. М., 2001. С. 298-305.

16 Проблемы суверенитета в Российской Федерации. М., 1994; Крылов Б.С. Государственный суверенитет в России: как его понимают в Казани // Журнал российского права. 2002. № 11. С. 13-24.

17 Крылов Б.С. Государственный суверенитет: современные проблемы // Конституционное и муниципальное право. 2008. № 6. С. 2-6.
}

Она была опубликована в 2006 г., но не утратила актуальности и сегодня. В работе речь идет о том, что должен получать студент в процессе обучения, какими должны быть учебники, каковы методы обучения в новых условиях. Борис Сергеевич пишет, что мы нередко стремимся дать студентам как можно больше знаний. Это приводит, в частности, к значительному увеличению объема учебников и учебных пособий. Но основательно изучить и тем более систематизировать огромную массу сведений, содержащихся в лекциях и учебниках, студент часто практически не в состоянии. Тем более эти сведения нередко быстро устаревают. Вместе с тем объем научных знаний оставляет подчас мало времени и возможностей на то, чтобы внедрить в учебный процесс формирование практических навыков, которые необходимы каждому юристу $^{18}$. Трудно не согласиться с этим.

Борис Сергеевич Крылов отдал много сил повышению уровня гуманитарного развития студентов, их патриотическому воспитанию. Он располагал к себе своей интеллигентностью, своими глубокими научными и жизненными познаниями. Его любили студенты, видя в нем живую легенду той далекой героической эпохи, к нему внимательно прислушивались аспиранты, ценили и уважали коллегипреподаватели, отдавая должное его знаниям, эрудиции, замечательным качествам его души и характера.

Кончина Бориса Сергеевича Крылова это невосполнимая утрата, которую понесли кафедра конституционного и муниципального права, Университет имени О.Е.Кутафина, юридическая наука в целом. Это тяжелая утрата для всех, кто знал Бориса Сергеевича, кто работал с ним, кто учился у него.

Светлая память о нем останется навсегда в наших сердцах!

18 Крылов Б.С. Российское высшее юридическое образование перед лицом новых трудностей // Наука в XXI веке. Юридическое образование в современной России: состояние и перспективы развития. М., 2006. С. 43-48. 


\section{Библиография}

1. Крылов Б. С. Парламент буржуазного государства. Политическая сущность и формы парламента и парламентаризма на современном этапе. - М., 1963.

\section{References}

1. Krylov B. S. Parlament burzhuaznogo gosudarstva. Politicheskaya sushchnost' i formy parlamenta i parlamentarizma na sovremennom etape. - M., 1963.

Материал поступил в редакцию 29 ноября 2013 г. 